\title{
Identification, prediction and mitigation of sinkhole hazards in evaporite karst areas
}

F. Gutiérrez (1), A.H. Cooper (2) and K.S. Johnson (3)

(1) Corresponding author: Edificio Geológicas; University of Zaragoza; C/. Pedro Cerbuna, 12; 50009 Zaragoza; Spain; Phone: 34976 761090; Fax: 34976 761106; Email: fgutier@unizar.es

(2) British Geological Survey; Keyworth; Nottingham; NG12 5GG; UK

(3) Oklahoma Geological Survey; Energy Center; 100 E. Boyd; Norman; Oklahoma 73019-0628; USA

\section{Copyright the authors and their respective institutions, please respect copyright;}

for private study use only. Paper published in Environmental Geology. 2008. Vol 53. 1007-1022 and as DOI 10.1007/s00254-007-0728-4

Abstract Sinkholes usually have a higher probability of occurrence and a greater genetic diversity in evaporite terrains than in carbonate karst areas. This is because evaporites have a higher solubility, and commonly a lower mechanical strength. Subsidence damage resulting from evaporite dissolution generates substantial losses throughout the world, but the causes are only well-understood in a few areas. To deal with these hazards, a phased approach is needed for sinkhole identification, investigation, prediction, and mitigation. Identification techniques include field surveys, and geomorphological mapping combined with accounts from local people and historical sources. Detailed sinkhole maps can be constructed from sequential historical maps, recent topographical maps and digital elevation models (DEMs) complemented with building-damage surveying, remote sensing, and high-resolution geodetic surveys. On a more detailed level, information from exposed paleosubsidence features (paleokarst), speleological explorations, geophysical investigations, trenching, dating techniques, and boreholes, may help to recognize dissolution and subsidence features. Information on the hydrogeological pathways including caves, springs and swallow holes, are particularly important especially when corroborated by tracer tests. These diverse data sources make a valuable database - the karst inventory. From this dataset, sinkhole susceptibility zonations (relative probability) may be produced based on the spatial and temporal distribution of the features and good knowledge of the local geology. Sinkhole distribution can be investigated by spatial distribution analysis techniques including studies of preferential elongation, alignment and nearest neighbor 
analysis. More objective susceptibility models may be obtained by analyzing the statistical relationships between the known sinkholes and the conditioning factors, such as weather conditions. Chronological information on sinkhole formation is required to estimate the probability of occurrence of sinkholes (number of sinkholes $/ \mathrm{km}^{2}$ year). Such spatial and temporal predictions, derived from limited records and based on the assumption that past sinkhole activity may be extrapolated to the future, are noncorroborated hypotheses. Validation methods allow us to assess the predictive capability of the susceptibility maps and to transform them into probability maps. Avoiding the most hazardous areas by preventive planning is the safest strategy for development in sinkhole-prone areas. Corrective measures could be to reduce the dissolution activity and subsidence processes, but these are difficult. A more practical solution for safe development is to reduce the vulnerability of the structures by using subsidence-proof designs.

Key words: sinkholes, evaporite karst, hazard assessment, mitigation

\section{Introduction}

The dissolution of soluble rocks and deposits at the surface, or in the subsurface combined with internal erosion and deformational processes, can produce closed depressions called sinkholes or dolines. These hollows characterize karst landscapes and are usually sub-circular in plan varying in size up to hundreds of meters across, and typically from a few meters to tens of meters deep (Williams 2003). The word doline, derived from the Slavic word dolina, is a term mainly used by European geomorphologists. The term sinkhole is most commonly used in the international literature when dealing with engineering and environmental issues. The generation of these karstic depressions is related to the dissolution of carbonate and evaporitic rocks. Sinkholes in evaporite karst areas occur worldwide (Klimchouk et al. 1996), and pose numerous practical problems, but compared with sinkholes in carbonate karst terrains they have received relatively scarce attention. Evaporite karst sinkholes also commonly show a greater genetic diversity (Gutierrez et al. 2008b). Because of the higher solubility and lower mechanical strength of evaporites, their susceptibility to sinkhole 
formation is greater than that of carbonate karst terrains. The solubilities of gypsum $\left(\mathrm{CaSO}_{4} 2 \mathrm{H}_{2} \mathrm{O}\right)$ and halite $(\mathrm{NaCl})$ in distilled water are 2.4 and $360 \mathrm{gr} / \mathrm{l}$, respectively. By comparison, the solubilities of calcite and dolomite minerals in natural environments are commonly lower than $0.5 \mathrm{gr} / \mathrm{l}$, depending on the $\mathrm{pH}$, which is largely controlled by the $\mathrm{CO}_{2}$ partial pressure (Ford and Williams 1989). Gypsum dissolution rates as high as 29 $\mathrm{mm} /$ year have been measured in unconfined hydrogeological conditions in western Ukraine (Klimchouk and Aksem 2005). In addition, the evaporites tend to have a more ductile rheology than carbonate rocks, and their commonly lower strength may be reduced substantially on a human time scale by dissolution processes. Another peculiarity of evaporite karst is that subjacent dissolution may cause ground subsidence on a regional scale. When these subsidence phenomena operate over long time periods, they produce gravitational morphostructures, which may be up to several hundred kilometers in extent and hundreds of meters in structural relief. These include depositional basins that may have geomorphic expression (Christiansen 1967; Johnson 1989; Hill 1996), large collapse depressions (Gutiérrez 1996), concordant synclinal valleys (Gustavson 1986), monoclinal flexures (Anderson and Hinds 1997; Warren 1999; Cooper 2002; Kirkham et al. 2002), and grabens (Cater 1970; Doelling 2000; Gutiérrez, 2004). Additionally, where large-scale synsedimentary subsidence affects valley reaches, it may generate dissolution-induced basins more than $100 \mathrm{~m}$ deep and several kilometers long filled with alluvial deposits (Gutiérrez 1996; Benito et al. 2000; Guerrero et al.2007).

In evaporite karst areas, gravitational deformation of the ground during sinkhole development may cause severe damage to buildings and other man-made structures (Cooper and Waltham 1999; Gutiérrez and Cooper 2002), including roads (Benson and Kaufman 2001), railways (Guerrero et al. 2004; Gutiérrez et al. 2007a), dams (Gutierrez et al. 2002; Johnson 2008b), canals and ditches (Gutiérrez et al. 2007a); even nuclear power stations like Neckarwestheim in Germany have been affected (Prof. H. Behmel, pers. comm.) (Fig. 1). Subsidence phenomena caused by evaporite dissolution have a substantial detrimental effect on development in numerous regions of the world (Cooper and Calow, 1998; Gutiérrez et al. 2008a; Johnson, 2008a), and individual sinkhole events may have a large financial impact. For example, in the Spanish cities of Oviedo and Calatayud situated on cavernous gypsum, the direct economic losses caused by single collapse events that affected buildings in 1998 and 2003 were estimated to be 18 
and 4.8 million euros, respectively (M. Gutiérrez-Claverol pers. comm. and Gutiérrez et al. 2004). Sinkholes may also cause the loss of human lives when they occur in a catastrophic way. Thirty four people have been killed by sudden collapses in the dolomite karst of the Far West Rand of South Africa (Bezuidenhout and Enslin 1970). Several people have been swallowed and injured by sinkholes resulting from halite dissolution on the Dead Sea coast of Israel (Frumkin and Raz 2001). Other sinkhole problems are related to hydrogeology and hydraulic structures. Sinkholes can act as water-inlets connected to high-transmissivity karstic aquifers and cave systems making the impoundment of water in reservoirs difficult (Pearson 1999; Milanovic 2000; Johnson 2008b). They can facilitate the rapid pollution of the groundwater (Paukstys and Narbutas 1996), and in places might affect the safety of sensitive structures such as the radioactive waste WIPP repository in New Mexico (Hill 2003). Moreover, these topographic depressions are frequently prone to flooding either by the concentration of surface runoff or by groundwater flooding when the water table rising above their ground level. This paper presents a basic methodological review of the assessment and mitigation of sinkhole hazards in evaporite karst areas, contrasting them with the differences these phenomena show in carbonate karst terrains.

\section{Processes, factors and the impact of human activity}

Several relatively similar genetic classifications of sinkholes have been recently published (Williams 2003; Beck 2004; Waltham et al. 2005). However, the study of paleokarst reveals that the development of sinkholes in evaporite karst terrains involves a wider range of processes than those used by the aforementioned classifications. Guerrero et al. (2008b) proposed a new genetic classification of sinkholes applicable to evaporite karst areas. It has similarities to Beck’s (2004) sinkhole classification and the most widely used landslide classifications, such as the one proposed by Cruden and Varnes (1996). With the exception of solution dolines, the scheme describes the sinkholes with compound terms: the first descriptor refers to the material affected by internal erosion and deformational processes (cover, bedrock or caprock), and the second indicates the main type of process involved (collapse, suffosion or bending) (Fig. 2). In practice, more than one material type and several processes can be involved in the generation of many sinkholes. These complex sinkholes, classified as polygenetic by Williams (2003) and Beck (2004), could be described using combinations of the 
proposed terms with the dominant material or process followed by the secondary one (e.g. cover and bedrock collapse sinkhole, cover suffosion and bending sinkhole).

Two main genetic groups of sinkholes may be recognized: the solution sinkholes, generated by the differential dissolutional lowering of the ground in areas where the evaporites are exposed at the surface (bare or uncovered karst), and the different types of sinkholes resulting from both, subsurface dissolution and downward gravitational movement (internal erosion and deformation) of the overlying material. Solution sinkholes are generally shallow depressions that may reach up to several hundred meters across. The second group is obviously the most important from a ground stability and engineering perspective. The sinkholes generated over dissolutional voids by the upward propagation (stoping) caused by collapse of the cavity roofs are designated as bedrock collapse or caprock collapse sinkholes, depending on whether the cavity migrates through karst or non-karst lithologies, respectively (Fig. 2). The formation of these sinkholes may be related to deep-seated dissolutional voids involving the generation of breccia pipes that may reach several hundred meters in height (Johnson 1989; Ford 1997; Yarou and Cooper 1997; Warren 1999). These sinkholes commonly show a low probability of occurrence (Beck, 2004; Waltham et al. 2005), and are generally sharp-edged depressions up to a few tens of meters in diameter. The sinkholes generated by the progressive interstratal dissolution of the evaporitic bedrock and the concurrent gradual bending of the overlying evaporitic or non-karstic bedrock may be termed bedrock bending or caprock bending sinkholes, respectively (Fig. 2). This type of subsidence, which is particularly frequent in sequences with halite beds, may result in depressions and troughs several kilometers in length (Kirkham et al. 2002).

Three main end members can be differentiated in areas where the evaporitic bedrock is mantled by a cover of allogenic sediments or residual soils (Fig. 2): (1) Cover bending sinkholes are caused by the differential lowering of the rockhead, which may lead to the gradual bending of the overlying mantle. These are commonly shallow depressions that may reach several hundred meters in length. In this case, a thick karstic residue may form between the cover and the "unweathered" evaporitic bedrock. (2) Cover suffosion sinkholes result from the downward migration of the cover through dissolutional voids (raveling) and its ductile sagging. A wide range of processes may be involved in the downward transport of the particles, including down-washing and viscous or 
cohesionless granular sediment gravity flows. These are commonly bowl-shaped hollows, and their diameter can range from a few meters to tens of meters. (3) Cover collapse sinkholes form by the collapse of soil arches resulting from the upward propagation of breakdown cavities developed through a cohesive and brittle cover above dissolutional voids. These sinkholes have scarped edges at the time of formation, and are commonly a few meters across to less than 10 meters, although in places they may reach several tens of meters in diameter. The cover collapse and cover suffosion sinkholes account for the vast majority of the sinkhole damage, since these are the types with the higher probabilities of occurrence (Beck 2004; Waltham et al. 2005). In many cases it is not possible to determine whether a collapse sinkhole in a mantled karst area corresponds to a cover collapse or to a cover and bedrock collapse sinkhole.

There are several important practical aspects regarding the formation of collapse sinkholes. Of major concern is that they may form in a catastrophic way without showing any previous noticeable warning signs. After formation they may grow in size because their scarped sides tend to degrade by mass wasting and erosion processes as they evolve from a cylindrical to a cone then a bowl-shaped geometry, an evolution, which may be very rapid in cover collapse sinkholes. The volume of the collapse sinkholes at the time of formation provides a minimum estimate of the volume of the subsurface cavities since voids may remain unfilled and the collapse material may bulk and undergo a reduction in density (Cooper, 1986).

An additional widely used term is buried sinkhole. This type refers to any sinkhole without topographic expression, regardless of its origin. It is important to note that "buried" does not mean necessarily inactive, since they may correspond to artificially filled recent sinkholes or to sinkholes developed in an area where the aggradation rate counterbalances the subsidence rate. On the other hand, old buried sinkholes may pose subsidence problems due to differential compaction or reactivation, especially when human activities involve the application of loads or changes in the natural hydrological regime.

Two types of processes are involved in the generation of collapse, suffosion and bending sinkholes: subsurface dissolution (hydrogeological component) and downward movement of the overlying material due to lack of basal support (mechanical 
component). From a practical viewpoint, active dissolution processes in carbonate karst areas are relatively slow (Beck 2004) and the effects attributable to dissolution alone over a short timescale are relatively uncommon. In contrast, dissolution is very rapid in evaporite karst areas, especially those with unsaturated rapid turbulent water flows and/or those areas with salt deposits. It is important to note that subsidence processes can be very rapid and may be related to dissolutional voids generated in the past. This means that sinkholes may occur in areas over cavernous soluble bedrock where no active dissolution is currently occurring.

The main factors that control evaporite karstification process are discussed by Gutiérrez and Gutiérrez (1998), Klimchouk (2000) and Jeschke et al. (2001), they include:

(1) The composition of the evaporites and any adjacent aquifers (lithology and mineralogy).

(2) The structure and texture of the soluble rocks and any adjacent aquifers.

(3) The amount of water flowing in contact with the evaporites and its physicochemical properties (including saturation index and temperature).

(4) The flow regime and groundwater conditions (laminar or turbulent, phreatic or vadose).

(5) The variations in the water table (or piezometric level).

The internal erosion and deformational processes are primarily controlled by different factors (Waltham et al 2005), including:

(1) The thickness of the sediments overlying the karstification zone and cavities that can be generated either by dissolution or upward stoping.

(2) The mechanical properties of the covering materials, which may change by dissolution processes and variations in the water content.

(3) Geometry and size of the subsurface voids; primarily the span of the cavity roofs.

(4) Position and changes of the water table (or piezometric level).

Frequently, natural or anthropogenic changes in the karst environment can accelerate the processes involved in the generation of sinkholes, favoring or triggering their occurrence or reactivation. Sinkholes whose genesis has been favored or determined by human activities are commonly termed induced sinkholes. According to Waltham et al. 
(2005), the vast majority of the active sinkholes are induced or accelerated by human activity. The main changes and activities that may induce the occurrence of sinkholes are listed in Table 1.

\section{Identification of sinkholes and subsidence areas}

The selection and application of mitigation measures aimed at reducing sinkhole risk generally requires the recognition of the existing sinkholes (identification) and the delineation of the areas where future new sinkholes are likely to occur (prediction). It is also important to gather information on the size and frequency of the sinkhole events, and on the subsidence mechanisms and rates. However, the identification of areas affected by evaporite-dissolution subsidence is usually a difficult task (Gutiérrez et al. 2007a). Sinkholes are frequently masked by anthropogenic activities, such as filling and development, or natural aggradation or erosion processes may obliterate them. Commonly, sinkholes may have a very subtle geomorphic expression or the collapse created by underground processes may not yet have reached the ground surface. In order to partially overcome these difficulties, it is essential to investigate as many sources of surface and subsurface information as possible to provide data about the past and current subsidence activity in the study area.

\section{Surface data}

Aerial photographs and satellite images

Aerial photographs, especially large-scale color stereoscopic images, are a very useful tool for identifying sinkholes. Their main limitation is that, depending on the scale and definition of the images, it may not be possible to pinpoint small or shallow sinkholes. Old aerial photographs are frequently very helpful for the identification of filled sinkholes or those that are now covered by buildings or human structures (Fig. 3). The detailed interpretation of photographs taken on different dates allows the chronology of recently formed sinkholes to be constrained. The interpretations help to obtain minimum estimates of the probability of sinkhole occurrence and allow the analysis of the spatio-temporal distribution patterns of the subsidence phenomena. Low sun-angle photographs, with conspicuous shadows can emphasize subtle topographic features (McCalpin 1996) and may be practical for the detection of sinkholes with poor geomorphic expression. A complementary technique is the analysis of airborne and 
satellite multispectral and thermal images which may be used to distinguish surface terrain patterns and to extract variations in moisture, vegetation, color and temperature that may be related to sinkholes and subsidence areas (e.g. Cooper 1989).

\section{Field surveys}

Thorough reconnaissance of the ground may locate sinkholes not identifiable on aerial photographs, due to their reduced size, depth or vegetation cover. A database template may be used for the description of each sinkhole (Cooper et al. 2001, Cooper 2008), including a space for diagrams and entries covering aspects including locality coordinates, geometry, orientation, dimensions, age, relative chronology (cross-cutting relationships, preservation degree, vegetation), signs of instability, proximity to human structures, and other observations. Some features may help to detect shallow subsidence depressions and filled sinkholes. These include anthropogenic fills with subcircular patterns, the presence of swampy areas, or the growth of palustrine or halophilous vegetation. Commonly, the application of intrusive or non-intrusive techniques, such as trenching, probing, drilling or geophysical surveys, is needed to determine whether these anomalous characteristics correspond to sinkholes. Direct inspections also allow the detection of instability signs, such as cracks, scarps or pipes. These features provide information on the activity and chronology of the sinkholes and may serve as indicators for anticipating the location of future sinkholes. Sinkhole activity in developed areas becomes apparent through pavement and building deformation, disrupted services and other structures. Mapping the subsidence damage, using a damage ranking system such as that established by the National Coal Board (N.C.B. 1975), provides information on the spatial distribution of the subsidence, and may help to infer the main natural and anthropogenic factors that control the dissolution and subsidence processes (Gutierrez and Cooper 2002). Building damage can also be recorded on proforma record sheets to provide the data in a GIS and database-friendly format (Cooper et al. 2001, Cooper 2008).

\section{Topographic and geodetic information}

The contour lines of detailed topographic maps may depict subsidence depressions not detectable by means of field surveys and aerial photograph interpretations (Kasting and Kasting 2003). In some areas, the contour lines and local names on old topographic maps have proved highly valuable for pinpointing sinkholes obliterated by artificial fill 
or development (Gutiérrez et al. 2007b) (Fig. 3). Several geodetic techniques, like InSAR (Baer et al. 2002; Al Fares 2005), GPS, photogrammetry, and high-resolution digital elevation models (DEMs) such as those produced by LIDAR, may be applied to locate sinkholes and estimate subsidence rates accurate to a few millimeters per year (Waltham et al. 2005). GIS techniques, such as applying wide color ramps restricted to narrow elevation ranges on DEM and LIDAR data allow subsidence features and patterns to be picked out easily.

\section{Oral and documentary information}

In some regions, information from local residents may substantially improve the sinkhole inventory, providing data on the spatial and temporal distribution of undetected and filled sinkholes (Cooper, 1986; Beck 1991). It is important to conduct systematic interviews asking for the location of sinkholes, their chronology, and possible relationship with any triggering or conditioning factor, dimensions, morphology, orientation, subsidence mechanisms, and reactivations. Abundant information is frequently obtained from the people involved in filling the hollows. It must be born in mind that some landowners may be reluctant to provide any data on sinkhole occurrences, to avoid the depreciation of their property. Additional information from written documents, such as local newspapers or reports from public institutions and private companies, may provide information on the characteristics, situation and chronology of sinkholes.

\section{Paleokarst features}

Paleosinkholes and subsidence structures exposed in natural and artificial outcrops offer valuable information about sinkhole formation, including where they have occurred in the past and their approximate sizes. They are also important for showing how sinkholes were formed and the subsidence processes that have occurred. Furthermore, they help to define where sinkholes may occur in the future (Fig. 4). Experience from many areas demonstrates that sinkholes commonly result from the reactivation of pre-existing cavities and subsidence structures. These observations indicate that paleosinkholes may be used as a tool for identifying locations highly susceptible to subsidence (Gutiérrez 1998; Guerrero et al. 2004) (Fig. 4). Additional information on the chronology and deformational history of subsidence structures can be gained by applying the 
methodologies used for the paleoseismological investigation of faults exposed in artificial trenches (McCalpin 1996).

\section{Subsurface data}

Speleological exploration

A highly valuable source of information is speleological exploration. Unfortunately it cannot be used in many subsidence-prone or phreatic situations. The examination and mapping of underground cavities provides data on the distribution of the accessible voids and the location of the points where active undermining processes (stoping, suffosion and bending) affecting the cavity ceilings may create new sinkholes in the near future. These unstable areas are revealed by the presence of collapse chimneys and bending structures in the cavity ceilings, and debris cones in the cavity floors produced by collapse or suffosion processes (Fig. 5). The fresh or degraded appearance of these features may be utilized to assess the relative likelihood of new sinkhole occurrences. Detailed maps of gypsum caves in the Western Ukraine (Klimchouk and Andrejchuk 2005) and in the Ural Region (Andrejchuk and Klimchouk 2002) show the distribution of breakdown cupolas and cones. These are probably the most reliable sinkhole susceptibility maps ever produced, even though they identify a process under way rather than a prediction of collapse.

\section{Geophysical prospecting}

Geophysical exploration techniques can be used to detect anomalies and changes in the physical properties of the ground that may correspond to cavities (air-, water-, or sediment-filled), subsidence structures (raveling zones, breccia pipes, synclinal sags, downthrown blocks), irregular rockhead topography, or buried sinkholes. In most cases, the characteristics of the anomalies need to be confirmed by intrusive methods such as probing, drilling or trenching. There are a wide variety of methods whose applicability and suitability depends largely on the available budget, geological context (bare, mantled or interstratal karst, type of surficial deposits), topography, expected type of dissolution and subsidence structures, presence of interfering factors such as man-made services, and the required penetration and resolution. A good option is to apply two or more geophysical methods and compare results. Reviews on the geophysical methods used in karst areas have been presented by Hoover (2003) and Waltham et al. (2005). Some of the main advantages and disadvantages of the methods are presented in Table 
2. It is advisable to use a phased sequence of investigation using geophysics on sites prior to drilling and probing; "anomalous" and "normal” areas can then be identified and targeted for investigation by drilling (Patterson et al. 1995). This approach has proved very effective for numerous commercial site investigations in Ripon over the past 10 years.

\section{Probing and drilling}

Probing and drilling provide valuable information on the nature and geotechnical properties of the ground and allow the recognition of voids and sediments disturbed by subsidence processes including raveling zones and breccia pipes. These may be seen in the core or located in the borehole by the loss of penetration resistance or drilling fluids. However, these techniques are expensive and time-consuming have other limitations. The normal site investigation practice of wide-spaced boreholes means that they may easily miss cavities, and stoping or raveling structures, consequently, to be certain of ground conditions,a program of deep and closely spaced borings is required (Cooper and Calow 1998). Such an array may not allow the satisfactory identification of bending subsidence structures (Fig. 2). Furthermore, the interpretations derived from borehole data may have a high degree of uncertainty due to the complex, sometimes chaotic, underlying geology in karst areas. Cored drilling is the most satisfactory method, but open hole drilling with expert identification of the chippings samples can be costeffective when combined with detailed records of drilling rates. The creation of cavities in highly soluble salts during and after drilling operations may be prevented using nearly saturated drilling fluids and casing the boreholes to avoid the circulation of water from any of the intersected aquifers (Johnson, 1989). It is important that any boreholes for site investigation are properly grouted after use. In gypsum it is important to use a sulfate-proof grout and in other evaporites a grout that will perform in the particular saline conditions. If the boreholes are not grouted properly they can become the focus for dissolution and may themselves lead to subsidence events. In the Ukraine a borehole drilled into a cave caused dissolution by aggressive drainage of surface water forming a pipe several meters across (Alexander Klimchouk, pers. comm.). In Israel, dissolution in salt on the site of a borehole to investigate the sinkhole-prone sequence caused a subsidence crater to open up near the Dead Sea (Mark Talesnick pers. comm. 2003). Drilling into breccia pipes and unstable ground is potentially hazardous and 
investigation companies should carry out a risk assessment of sites before drilling; geophysical information can help in this respect.

\section{Trenching}

Trenching provides an opportunity for detailed study of the stratigraphy and structure of the deposits, and when complemented with the application of absolute dating techniques, is a very useful methodology for sinkhole investigation in mantled karst settings. This methodology, widely used in paleoseismological (e.g. McCalpin 1996) and landslide investigations (e.g. Gutiérrez et al. 2005a), may provide extensive practical information about several aspects including (Gutiérrez et al. 2007a): (1) The nature of geophysical anomalies and topographic depressions that have an uncertain origin. (2) The precise limits of filled and poorly-defined sinkholes. (3) The structure of the deposits (synclines, failure planes, raveling zones) and insight into the subsidence mechanisms and magnitude (cumulative displacement). (4) Retrodeformation analysis of the deposits by means of the progressive restoration of the sedimentary bodies; this may allow the interpretation of multiple subsidence episodes (Figure 6). (5) Absolute dating techniques, primarily radiocarbon and luminescence (OSL and TL) methods. These may be used to obtain mean subsidence rates and constrain the timing of the subsidence episodes (Fig. 6). The inferred evolution of particular sinkholes from trenching may be used to forecast their future behavior. Closely allied with trenching the stripping of topsoil or overburden can show the positions of subsidence features on a site during construction.

\section{Hydrogeological investigations}

Understanding the hydrogeology of the study area is a crucial aspect of sinkhole hazard analysis. The groundwater flow is the geological agent responsible for the karstification of evaporite rocks and commonly one of the most important conditioning and triggering factors involved in the generation of sinkholes. Numerous aspects need to be investigated especially the position of the water table (or piezometric level) and how it changes through time and space, either naturally or by anthropogenic means. It is important to find out whether the evaporites and the overlying sediments are affected by a downward vadose flow or by a phreatic/artesian flow controlled by the piezometric gradient. One way this can be done is by a borehole monitoring of groundwater levels using nested piezometers (Lamont-Black et al., 2005). A relevant factor, that may 
significantly influence suffosion processes in mantled karst settings, is the position of the water table with respect to rockhead. The groundwater flow velocity and flow path are also important and these may be investigated by means of tracers. The hydrochemistry of the groundwater and saturation index with respect to the main evaporitic minerals give indications of how aggressive the water is and how fast dissolution will proceed. Lastly, the impact of human activities on the natural hydrology should be investigated and recorded.

\section{Spatial and temporal prediction}

Once the pre-existing sinkholes and areas affected by subsidence have been identified and mapped, the next step in the hazard analysis is to predict the spatial and temporal distribution of future sinkholes. It is important to know where sinkholes will occur in the future, when they will form, with what frequency, how they will develop, what size they will reach and their likely mechanism of collapse.

\section{Temporal prediction}

The temporal prediction of sinkholes has two facets; one is the anticipation of the precise future moment or time interval when sinkholes will occur, and the other is the assessment of their frequency or probability of occurrence. At the present time, it is not possible to satisfactorily predict when and where an individual sinkhole will form. Monitoring systems like the one recently installed in the Italian village of Camaiore (V. Buchignani, pers. comm.) may help. This system provides continuous records of potential precursors such as subsurface microdeformation, variations in the water table, and subtle changes in the elevation, which may help to anticipate individual collapse sinkholes. Another predictive strategy is the use of a good understanding of the temporal patterns of hydrological triggering factors, such as rainstorms, floods or major irrigation and water table decline periods. Correlation with these events may be used to forecast the times of year that are susceptible to a higher frequency of sinkhole formation, such as periods of intense irrigation, flood or rainfall.

The sinkhole frequency, or probability of occurrence, can be regarded as the number of sinkhole events per year per unit area. A probability of occurrence of 0.1 sinkhole $/ \mathrm{km}^{2}$ year means that on average in a $10 \mathrm{~km}^{2}$ area, one sinkhole a year is expected to occur. 
Alternatively, it means that there is a statistical probability of $100 \%$ for a sinkhole to occur in the area each year (mean annual probability). Chronological information about the sinkhole occurrences (either a precise age or an age range) is strictly necessary to be able to estimate temporal frequency values. It is important to note that in areas where no chronological data are available, no frequency assessments can be carried out and a higher sinkhole density does not necessarily imply a higher probability of occurrence. The calculation of the probability of occurrence must be based on a sinkhole inventory which should be as complete as possible covering a representative time period (Beck 1991). The validity of the obtained frequency will depend on the completeness and quality of the available data derived from the different sources of information (reviewed in the previous section). In most cases we are not able to identify all the sinkhole events that occurred during the considered time span. Consequently this results in a minimum or optimistic sinkhole frequency. In the gypsum karst of Ripon (NE England), there is a reasonable record of sinkhole events (Cooper, 1986, 1998) which gives an estimated probability of occurrence of 0.05 major sinkholes $/ \mathrm{km}^{2}$ year based on $6.5 \mathrm{~km}^{2}$ and the past 100 years records. Using information from 1980, the time of the resurvey, to 2000 gives 21 major events in 20 years over $6.5 \mathrm{~km}^{2}$ equating with 0.17 sinkholes $/ \mathrm{km}^{2}$, or one every 6 years. The events are clustered in some places, consequently, the likelihood of a subsidence happening in these places is greater. These data underline the incompleteness of the recorded events and the bias in the historical data towards the time when the survey was undertaken. The data also show a bias to major events, which are recorded, while small events are not normally noted. A probability of 44 cover collapse sinkholes $/ \mathrm{km}^{2}$ year has been calculated by Gutiérrez et al. (2007a) in an intensely irrigated terrace of the Ebro River in the NE of Spain.

\section{Spatial prediction}

Several strategies may be applied to address the spatial prediction of sinkholes. A commonly used approach is the delineation of the a priori more susceptible areas to sinkhole events by an expert, based on geological criteria and the known information on the spatial and temporal distribution of previous sinkholes. Some aspects related to the spatial distribution and geometry of the sinkholes may be used to produce or refine the susceptibility maps. 
The clustering or dispersion of sinkholes may be quantified using nearest neighbor analysis (Williams 1972). This analysis may be applied to test whether the generation of new sinkholes is influenced by the location of the pre-existing sinkhole population (Kemmerly 1982), and if the sinkhole distribution has any statistical value for the prediction of future sinkholes (Hyatt et al. 1999; Gutiérrez-Santolalla et al. 2005b). If the analysis demonstrates that new sinkholes tend to form in the vicinity of previously existing ones, their surroundings may be considered as especially prone to subsidence. In areas where structurally-controlled sinkholes show preferred alignment and elongation trends, the analysis of such orientated data can be undertaken manually by plotting lineations though the centers of sinkholes (Cooper 1986) or by computer utilizing the Hough Transform method of analysis (Wadge et al. 1993). In these situations the following criteria could be applied for the delineation of susceptibility zonations (Gutiérrez-Santolalla et al. 2005b): (1) The areas next to the extremities of the sinkholes defined by the controlling azimuths may be considered as more susceptible than the rest of the sinkhole margins. (2) A higher susceptibility may be attributed to the belts of land between sinkholes aligned in the prevalent direction. A more objective approach is the elaboration of susceptibility zonations to analyze the statistical relationships between the known sinkholes (the “dependent” variable) and the available information on the conditioning factors (the “independent” variables) using GIS (Galve et al. 2006)

It is important to note that the temporal and spatial predictions derived from all these methodologies should be considered as non-corroborated hypotheses. This is because they are derived from a limited amount of data (spatial and temporal distribution of sinkholes, and conditioning factors) and the predictions implicitly assume that the subsidence phenomena in the future will have a rate and behavior similar to those in the past (Cendrero 2003). This may not be true, and the sinkhole hazard (probability and severity) in the future may be significantly higher, or lower, than it was in the past due to anthropogenic or natural changes in the factors that control the dissolution and subsidence processes. For these reasons, the reliability of the predictions should be checked with statistically independent data. The predictive capability of the susceptibility zonations may be evaluated using validation methods such as those used to check predictive landslide models (Remondo et al. 2003). Figure 7 shows how the validation of susceptibility maps with temporal data allows the transformation from 
susceptibility zonations (relative probability) into hazard maps (quantitative probability).

\section{Hazard and risk assessment}

The potential annual sinkhole risk in a given area may be estimated using the formula (Bell 1999):

$$
\mathrm{R}=\sum \mathrm{H} \times \mathrm{Ex} \mathrm{V}
$$

where $\mathrm{R}$ is the risk, expressed in terms of victims per year or financial losses per year; $\mathrm{H}$ is the hazard; $\mathrm{E}$ the exposure or elements at risk, referring to the population and the economic value of the properties and activities that may be affected by sinkholes; and V the vulnerability, given by the unitary fraction of the exposure that is expected to be damaged if affected by a sinkhole. The total annual risk corresponds to the sum of the estimated risk for each exposed human element. Preferably, the hazard should include two components; the probability of sinkhole occurrence, and the expected severity of the future sinkholes (Gutiérrez et al. 2007b). The severity refers to the physical scale of the subsidence processes and sinkholes that determine their capability to cause damage. This is basically the size of the sinkhole at the time of formation and the subsidence rate, which depends largely on the subsidence mechanism. In an ideal situation, it would be desirable to produce a scaling relationship between the magnitude and frequency of the sinkholes. This is commonly achieved for other hazardous geological processes including floods and earthquakes.

The sinkhole hazard and risk assessment may also be used to perform cost-benefit analysis. This compares the costs over time calculated for the sinkhole-affected project using the "with mitigation" and "without mitigation" scenarios (Cooper and Calow 1998). This analysis provides quantitative information on several practical aspects for the management of the sinkhole risk. It gives information on the cost-effectiveness of particular mitigation measures for a given period of time and the time period required for a mitigation measure to be paid off. It also identifies the most economically and socially advantageous mitigation measures for the life span of a project. In the situations where catastrophic sinkholes might endanger human lives, public safety should prevail 
over the economic criteria for the selection of mitigation measures, either preventive or corrective.

\section{Mitigation}

The safest mitigation strategy is the avoidance of the subsidence features and the areas most susceptible to sinkholes. This preventive measure may be applied prohibiting or limiting development in the most hazardous areas through land use planning and regulations (Paukstys et al. 1999; Richardson 2003). The preventive planning is commonly most effective when developed by local administrations (Pauksty et al. 1999). When sinkhole-prone areas are occupied by people, vulnerable buildings and infrastructure, the risk should be mitigated by reducing the activity and severity of the processes (hazard), the vulnerability, or both. Since the control of the subsurface dissolution and subsidence processes involved in the generation of sinkholes may be very difficult, safe mitigation commonly requires careful planning and the application of subsidence protected engineering designs. A critical design parameter is the maximum diameter of the sinkholes at the time of formation, as it determines the distance that has to be spanned to prevent the deformation of the engineered structure. Some corrective measures aimed at diminishing the activity of the processes (Milanovic 2000) include: (1) Preventing water withdrawal and the decline of the water table. (2) Lining of canals and ditches. (3) Using flexible pipes with telescopic joints. (4) Controlling irrigation. (5) Making the surface impermeable with geomembranes or geotextiles. (6) Using efficient drainage systems and diverting surface runoff. (7) Remediating sinkholes and clogging swallow holes. (8) Filling cavities in the soil or rock by grouting (Sowers 1996). However, filling cavities may block most of the flow paths concentrating underground flow along particular conduits and thus favoring focused dissolution (Cooper 1998). (9) Improving the ground by compaction or injection grouting to increase the strength and bearing capacity of the soils. (10) Construction of cutoff screens and grout curtains beneath dams to avoid ground water circulation beneath the structures.

Different types of engineering measures have been applied to protect structures from sinkhole development. These include: (1) Special foundations for buildings including raft or slab, reinforced strip and ring-beam foundations; these are strong foundations which distribute the load of the structures over large areas. Beam extensions to these foundations, especially at the corners of the structures, can offer more protection and 
prevent a cantilever situation developing on the edges of structures. Skin friction and end-bearing piles are commonly used to transfer the structural load to the soil cover or solid bedrock, respectively (Reuter and Tolma $\square$ Nv, 1990; Reuter and Stoyan, 1993; Cooper and Calow 1998; Waltham et al. 2005). (2) Linear infrastructures including roads and railways can be reinforced by incorporating tensile geogrids in the sub-base and embankments. This technique prevents catastrophic collapse, and can sag to act as a warning mechanism that collapse is occurring before it becomes a catastrophic failure; measures can then be taken to remediate the problem (Cooper and Saunders 2002). (3) Rigid structures like reinforced concrete slabs acting as ground bridges have been proposed to protect high-speed railways that cannot tolerate even slight settlement. An added degree of security could be gained by piling the slabs (Guerrero et al. 2004). (4) Sinkhole-resistant bridges can be built incorporating oversized foundation pads to the piers and a sacrificial pier design, so that the structure will withstand the loss of a pier (Cooper and Saunders 2002). Other non-structural measures aimed at reducing the financial losses and harm to people include: (1) Insurance policies to spread the cost generated by sinkholes among the people at risk. (2) Monitoring in problematical locations with highly vulnerable structures - where the settlement of the ground and the deformation of the structures can be instrumented with monitoring and warning systems (inclinometers, extensometers, geodetic measurements, laser or light transmitters and receptors). (3) Educational programs oriented to adequate the perception of the hazard among the public and decision makers to the objective likelihood of sinkhole occurrence (Buskirk et al 1999). (4) The fencing and warning signposting of sinkholes and sinkhole-prone areas.

\section{Conclusions}

Sinkholes in evaporite karst areas are in general more active and diverse in character than sinkholes developed in carbonate karst terrains. The differences are mainly because evaporites have a higher solubility, lower mechanical strength and some also have a more ductile rheology than the carbonate rocks. Two main situations for sinkhole development occur. At the surface, solution sinkholes form by corrosional lowering. Subsurface dissolution and the downward movement of overlying materials produce the second type, which are the most important from a ground instability and engineering perspective. The main subsidence mechanisms that form sinkholes include: collapse of 
soil or rock cavity roofs; downward migration of unconsolidated deposits through dissolutional voids (suffosion); and passive bending caused by progressive interstratal karstification or the differential lowering of the rockhead. Sinkholes caused by the dissolution of evaporites have a substantial detrimental effect in many regions of the World. The generation of sinkholes may cause severe damage to man-made structures and may threaten human lives when they occur in a catastrophic way. The selection and application of sinkhole mitigation measures should be based on sound hazard and risk assessments. The hazard assessment involves the identification and characterization of the existing sinkholes and karst features and the prediction of future subsidence phenomena. These include the areas where new sinkholes are more likely to occur, the probability of sinkhole formation, the expected subsidence mechanism and maximum initial size of the sinkholes (severity).

The recognition of sinkholes is frequently a difficult task that should be addressed by exploring as many sources of surface and subsurface information as possible. Surface data may be obtained from aerial photographs and satellite images, field surveys, building-damage maps, historical and recent topographical maps, accounts from local people, historical documents, exposed dissolution and subsidence features (paleokarst), and high resolution geodetic techniques (InSAR, photogrammetry, LIDAR and DEMs). The main sources of subsurface data are derived from speleological exploration, geophysical surveys, boreholes, trenching complemented with absolute dating techniques, and hydrogeological investigations. The reliability of future sinkhole prediction will depend largely on the completeness of the sinkhole/karst inventory and an understanding of the local geology and hydrogeology. Chronological information about past sinkhole events, either as a date or an age range, is indispensable for estimating a minimum probability of sinkhole occurrence (number of sinkholes $/ \mathrm{km}^{2}$ year). Although it is not currently possible to anticipate the precise location and timing of individual sinkholes, the installation of monitoring systems that provide a continuous record of potential precursors (microdeformations, surface deformations, changes in the water table etc.), might yield good results in the future.

Sinkhole susceptibility zonations (relative probability) may be produced. These should be based on a good knowledge of the geology, the spatial and temporal distribution of pre-existing sinkholes and other karst features (karst inventory) and spatial distribution 
analysis techniques (including preferential elongation and alignment, nearest neighbor analysis). More objective susceptibility models may be obtained by analyzing the statistical relationships between the known sinkholes and the conditioning factors. All these predictions are based on the underlying assumption that sinkhole activity in the future will have a behavior similar to that of the past. The predictions are commonly derived from incomplete records and should be considered as non-corroborated hypotheses. Temporal validation techniques may be applied to assess the predictive capability of the susceptibility maps and transform them into probability maps. Quantitative sinkhole hazard assessment (probability and severity) allows us to assess the potential damage that may be caused by sinkholes (risk) and to perform cost-benefit analyses. Avoidance of areas most susceptible to sinkhole activity is the safest mitigation strategy. In sinkhole-prone areas, it is difficult to control subsurface dissolution and associated sinkhole subsidence processes, consequently, safe development requires the application of subsidence-proof engineering designs.

Acknowledgements This work has been partially co-financed by the Spanish Education and Science Ministry and the FEDER (project CGL2004-02892/BTE). Dr Andrew Farrant, Dr Andrew Gibson and Mr Dave Bridge are thanked for reviewing the paper. AHC publishes with permission of the Executive Director, British Geological Survey (NERC).

\section{References}

Al-Fares RA (2005) The utility of Synthetic Aperture Radar (SAR) Interferometry in monitoring sinkhole subsidence: Subsidence of the Devil's Throat sinkhole area (Nevada, USA). In: Beck BF (ed) Sinkholes and the engineering and environmental impacts of karst. American Society of Civil Engineers. pp 541-547

Anderson NL, Hinds RC (1997) Glacial loading and unloading: a possible cause of rock salt dissolution in the Western Canada Basin. Carbonates and Evaporites 12, 1: 43-52.

Andrejchuk V, Klimchouk A (2002) Mechanisms of karst breakdown formation in the gypsum karst of the fore-Ural region, Russia (from observations in the Kungurskaja Cave). International Journal of Speleology 31: 89-114 
Baer G, Schattner U, Wachs D, Sandwell D, Wdowinsli S, Frydman S (2002) The lowest place on Earth is subsiding. An InSAR (interferometric synthetic aperture radar) perspective. Geological Society of America Bulletin 114: 12-23

Beck BF (1991) On calculating the risk of sinkhole collapse. In: Appalachian karst Kastning EH and Kastning KM (eds) Proceedings of the Appalachian Karst Symposium. National Speleological Society. Radford, Virginia: 231-236

Beck BF (2004) Soil piping and sinkhole failures. In: White WB (ed) Enyclopedia of caves. Elsevier: New York, pp 523-528

Bell FG (1999) Geological hazards. Their assessment, avoidance and mitigation. E \& FN Spon, London, 648 pp

Benito G, Gutiérrez F, Pérez-González A, Machado MJ (2000) Morphosedimentological features in Quaternary fluvial systems affected by solution-induced subsidence in the Ebro Basin, NE Spain. Geomorphology 33: 209-224

Benson RC, Kaufmann RD (2001) Characterization of a highway sinkhole within the gypsum karst of Michigan. In: Beck BF, Herring JG (eds) Geotechnical and Environmental Applications of Karst Geology and Hydrology, Balkema, Lisse, pp 103112

Bezuidenhout CA, Enslin JF (1970) Surface subsidence and sinkholes in the dolomitic areas of the Far West Rand, Transvaal, Republic of South Africa. Land Subsidence. International Association of Hydrological Sciences, Publication 89, pp 482-495

Buskirk ED, Pavelk MD, Strasz R (1999) Education about and management of sinkholes in karst areas: initial efforts in Lebanon. In: Beck BF (ed) Hydrogeology and engineering geology of sinkholes and karst. Proceedings of the Seventh Multidisciplinary Conference on Sinkholes and the Engineering and Environmental Impacts of Karst. Harrisburg/Hershey, Pennsylvania, April 10-14, 1999. A.A. Balkema, Rotterdam, pp 263266

Cater F (1970) Geology of the Salt Anticline Region in Southwestern Colorado. U.S. Geological Survey Professional Paper 637, 80 pp

Cendrero A (2003) De la comprensión de la historia de la Tierra al análisis y predicción de las interacciones entre seres humanos y medio natural. Discurso de recepción. Real Academia de Ciencias Exactas, Físicas y Naturales, Madrid, 60 pp

Christiansen EA. (1967) Collapse Structures near Saskatoon, Saskatchewan, Canada. Canadian. Journal of Earth Sciences 4: 757-767

Cooper AH (1986) Foundered strata and subsidence resulting from the dissolution of Permian gypsum in the Ripon and Bedale areas, North Yorkshire. 127-139 In: Harwood, GM and Smith DB (eds). The English Zechstein and related topics. Geological Society of London, Special Publication. No. 22. 
Cooper AH (1989) Airborne multispectral scanning of subsidence caused by Permian gypsum dissolution at Ripon, North Yorkshire. Quarterly Journal of Engineering Geology 22: 219-229

Cooper AH (1998) Subsidence hazards caused by the dissolution of Permian gypsum in England: geology, investigation and remediation. In: Maund JG, Eddleston M (eds) Geohazards in Engineering Geology. Geological Society. London, Engineering Geology Special Publication 15, pp 265-275

Cooper AH (2002) Halite karst geohazards (natural and man-made) in the United Kingdom. Environmental Geology 42: 505-512

Cooper AH (2008) The GIS approach to evaporite-karst geohazards in Great Britain. Environmental Geology. 53, 981-992.

Cooper AH, Farrant AR, Adlam KAM, Walsby JC (2001). The development of a national geographic information system (GIS) for British karst geohazards and risk assessment. In Beck BF and Herring JG (eds) Geotechnical and environmental applications of karst geology and hydrogeology. Proceedings of the Eighth Multidisciplinary Conference on Sinkholes and the Engineering and Environmental Impacts of Karst, April 1-4 ${ }^{\text {th }}$ Louisville, Kentucky, USA. Balkema Publishers, pp 125130.

Cooper AH, Calow RC (1998) Avoiding gypsum geohazards: guidance for planning and construction. British Geological Survey Technical Report WC/98/5, 57 pp http://www.bgs.ac.uk/dfid-kar-geoscience/database/reports/colour/WC98005_COL.pdf

Cooper AH, Saunders JM (2002) Road and bridge construction across gypsum karst in England. Engineering Geology 65: 217-223

Cooper AH, Waltham AC (1999) Subsidence caused by gypsum dissolution at Ripon, North Yorkshire. Quarterly Journal of Engineering Geology 32: 305-310

Cruden DM, Varnes DJ (1996) Landslide types and processes. In: Turner AK, Schuster RL (eds) Landslides. Investigation and mitigation. Transportation Research Board. National Research Council, special report 247, pp 36-75

Doelling HH (2000) Geology of Arches National Park, Grand County, Utah. In: Sprinkel DA, Chidsey TC, Anderson PB (eds) Geology of Utah's Parks and Monuments. Utah Geological Association Publication 28, pp 11-36

Eraso A, Trzhtsinskij Y, Castrillo A (1995) Dolinas de colapso y karst en yeso en la plataforma cámbrica del este de Siberia. Boletín Geológico y Minero 106:373-378

Ford, DC (1997) Principal features of evaporite karst in Canada. Carbonates and Evaporites 12, 1:15-23

Ford DC, Williams P (1989) Karst geomorphology and hydrology. Unwin Hyman, London, 601 pp 
Frumkin A, Raz E (2001) Collapse and subsidence associated with salt karstification along the Dead Sea. Carbonates and Evaporites 16, 2: 117-130.

Galve JP, Bonachea J, Remondo J, Gutiérrez F, Guerrero J, Lucha P, Cendrero A, Gutiérrez M, Sanchez JA (2006) Development and validation of sinkhole susceptibility models in mantled karst settings. A case study from the Ebro valley evaporite karst (NE Spain). Eng Geol (in press)

Guerrero J, Gutiérrez F, Lucha P (2004) Paleosubsidence and active subsidence due to evaporite dissolution in the Zaragoza city area (Huerva River valley, NE Spain). Processes, spatial distribution and protection measures for linear infrastructures. Engineering Geology 72: 309-329

Guerrero J, Gutiérrez F, Lucha P (2007) The impact of halite dissolution subsidence on fluvial terrace development. The case study of the Huerva River in the Ebro Basin (NE Spain). Geomorphology, (in press)

Gustavson TC (1986) Geomorphic development of the Canadian River Valley, Texas Panhandle: An example of regional salt dissolution and subsidence. Geological Society of America Bulletin 97: 459-472.

Gutiérrez F (1996) Gypsum karstification induced subsidence: Effects on alluvial systems and derived geohazards (Calatayud Graben, Iberian Range, Spain). Geomorphology 16: 277-293

Gutiérrez F (1998) Fenómenos de subsidencia por disolución de formaciones evaporíticas en las fosas neógenas de Teruel y Calatayud (Cordillera Ibérica). Ph D Thesis. University of Zaragoza, 569 pp

Gutiérrez F (2004) Origin of the salt valleys in the Canyon Lands section of the Colorado Plateau. Evaporite dissolution collapse versus tectonic subsidence. Geomorphology 57: 423-435

Gutiérrez F, Cooper AH (2002) Evaporite dissolution subsidence in the historical city of Calatayud, Spain: damage appraisal and prevention. Natural Hazards 25: 259-288

Gutiérrez F, Desir G, Gutiérrez M (2002) Causes of the catastrophic failure of an earth dam built on gypsiferous alluvium and dispersive clays (Altorricón, Huesca Province, NE Spain). Environmental Geology 43, 7: 842-851

Gutiérrez F, Lucha P, Guerrero J (2004) La dolina de colapso de la casa azul de Calatayud (noviembre de 2003). Origen, efectos y pronóstico In: G Benito, A DíezHerrero (eds) Riesgos naturales y antrópicos en Geomorfología, VII Reunión Nacional de Geomorfología, Toledo, pp 477-488

Gutiérrez-Santolalla F, Acosta E, Ríos S, Guerrero J, Lucha P (2005a) Geomorphology and geoarcheology of sackung features (uphill-facing scarps) in the Central Spanish Pyrenees. Geomorphology 69: 298-314 
Gutiérrez-Santolalla F, Gutiérrez-Elorza M, Marín C, Desir G, Maldonado C (2005b) Spatial distribution, morphometry and activity of La Puebla de Alfindén sinkhole field in the Ebro river valley (NE Spain). Applied aspects for hazard zonation. Environmental Geology 48: 360-369

Gutiérrez F, Galve JP, Guerrero J, Lucha P, Cendrero A, Remondo J, Bonachea J, Gutiérrez M, Sánchez JA (2007a) Typology, spatial distribution, origin and detrimental effects of the sinkholes developed in the alluvial evaporite karst of the Ebro River valley downstream Zaragoza city (NE Spain). Earth Surface Processes and Landforms, in press.

Gutiérrez F, Guerrero J, Lucha P (2007b) Quantitative sinkhole hazard assessment. A case study from the Ebro Valley evaporite alluvial karst (NE Spain). Natural Hazards, submitted.

Gutiérrez F, Calaforra J, Luch P. (2008b). A genetic classification of sinkholes illustrated from evaporite paleokarst exposures in Spain. Environ Geol. 53, 993-1006.

Gutiérrez M, Gutiérrez F (1998) Geomorphology of the Tertiary gypsum formations in the Ebro Depression (Spain). Geoderma 87: 1-29

Hill C (1996) Geology of the Delaware Basin, Guadalupe, Apache, and Glass Mountains, New Mexico and West Texas. Permian Basin Section-SEPM. Publication 96-39, $440 \mathrm{pp}$

Hill C (2003) Intrastratal karst at the Waste Isolation Pilot Plant Site, Southeastern New Mexico. In: Johnson KS, Neal JT (ed) Evaporite karst and engineering/environmental problems in the United States, Oklahoma Geological Survey Circular 109, pp 197-209

Hoover RA (2003) Geophysical choices for karst investigations. In: Beck BF (ed) Sinkholes and the engineering and environmental impacts of karst, American Society of Civil Engineers, Reston, pp 529-538

Hyatt J, Wilkes H, Jacobs P (1999) Spatial relationship between new and old sinkholes in covered karst, Albany, Georgia, USA. In Beck BF, Pettit AJ, Herring JG.

Hydrogeology and Engineering Geology of Sinkholes and Karst- 1999. Proceedings of the Seventh Multidisciplinary Conference on Sinkholes and the Engineering and Environmental Impacts of Karst. Harrisburg/Hershey, Pennsylvania, April 10-14, 1999. A.A.Balkema, Rotterdam, pp 37-44.

Jeschke AA, Vosbeck K, Dreybrodt W (2001) Surface controlled dissolution rates of gyppsum in aqueous solutions exhibit nonlinear dissolution kinetics. Geochimica et Cosmichimica Acta 65:27-34

Johnson KS (1989) Development of the Wink Sink in Texas, U.S.A., Due to Salt Dissolution and Collapse. Environmental Geology and Water Science 14, 2: 81-92.

Johnson KS (2008a) Evaporite-karst problems and studies in the United States. Environmental Geology. 53, 981-992. 
Johnson KS (2008b) Gypsum-karst problems in constructing dams in the United States. Environmental Geology. 53, 945-950.

Kasting KM, Kasting EH (2003) Site characterization of sinkholes based on resolution of mapping. In: Beck BF (ed) Sinkholes and the engineering and environmental impacts of karst. ASCE, Reston, pp 72-81

Kemmerly PR (1982) Spatial analysis of a karst depression population: Clues to genesis. Geological Society of America Bulletin 93: 1078-1086

Kirkham RM, Streufert RK, Kunk MJ, Budahn, JR, Hudson MR, Perry, W Jr. (2002) Evaporite tectonism in the lower Roaring Fork River valley, west-central Colorado. In: Kirkham RM, Scott RB, Judkins W (eds) Late Cenozoic evaporite tectonism and volcanism in west-central Colorado. Geological Society of America special paper 366, pp 73-99

Klimchouk A (2000) Dissolution and conversions of gypsum and anhydrite. In: Klimchouk A, Ford DC, Palmer AN, Dreybrodt W (eds) Spelogenesis. Evolution of karst aquifers. National Speleological Society Inc. Hunstville, pp 160-168

Klimchouk A, Lowe D, Cooper A, Sauro U (1996) Gypsum karst of the World. International Journal of Speleology 25 (3-4): 1-307

Klimchouk AB, Andrejchuk (2005) Karst breakdown mechanisms from observations in the gypsum caves of the Western Ukraine: implications for subsidence hazard assessment. Environmental Geology 48: 336-359

Klimchouk AB, Aksem SD (2005) Hydrochemistry and solution rates in gypsum karst: case study from the Western Ukraine. Environmental Geology 48: 307-319

Lamont-Black, J., Baker, A, Younger, PL, Cooper, AH (2005) Utilising seasonal variations in hydrogeochemistry and excitation-emission fluorescence to develop a conceptual groundwater flow model with implications for subsidence hazards: an example from Co. Durham, UK: Environmental Geology.48: 320-335

Lamoreaux PE, Newton JG (1986) Catastrophic Subsidence: An Environmental Hazard, Shelby County, Alabama. Environmental Geology and Water Sciences 8: 25-40

Llamas MR (1962) Estudio geológico-técnico de los terrenos yesíferos de la Cuenca del Ebro y de los problemas que plantean en los canales. Ministerio de Obras Públicas, Boletín 12, 192 pp.

Lucha P, Cardona F, Gutiérrez F, Guerrero J (2008) Natural and human-induced dissolution and subsidence features in the salt outcrop of the Cardona Diapir (NE Spain). Environmental Geology, 53, 1023-1035.

McCalpin JP, (1996) Field techniques in Paleoseismology. In: McCalpin JP (ed) Paleoseismology, Academic Press, San Diego, pp 33-83 
Michetti AM, Audemard FA, Marco S (2005) Future trends in paleoseismology: Integrated study of the seismic landscape as a vital toll in seismic hazard analysis. Tectonophysics 408: 3-21

N.C.B. (1975) Subsidence Engineers' Handbook, National Coal Board Mining Department, UK, pp 111

Milanovic PT (2000) Geological engineering in karst. Zebra, Belgrade, 347 pp

Patterson D, Davey JC, Cooper AH, Ferris JK (1995) The application of microgravity geophysics in a phased investigation of dissolution subsidence at Ripon, Yorkshire. Quarterly Journal of Engineering Geology (London) 28: 83-94

Paukstys WJ, Narbutas V (1996) Gypsum Karst of the Baltic Republics. In: Klimchouk A, Lowe D, Cooper A, Sauro U (eds). Gypsum karst of the World. International Journal of Speleology, 25 (3-4), pp 279-284

Paukstys B, Cooper AH, Arustiene J (1999) Planning for gypsum geohazard in Lithuania and England. Engineering Geology 52: 93-103

Pearson R (1999) Geology and safety of dams case histories in gypsum karst for Horsetooth Dam and Reservoir and Carter Lake Dam No. 2, Colorado Big Thompson Project, Ft. Collins and Loveland, Colorado. U.S. Department of the Interior. Bureau of Reclamation. USBR Technical Service Center D-8321, Denver

Reuter F, Stoyan D (1993) Sinkholes in carbonate, sulphate, and chloride karst regions: Principles and problems of engineering geological investigations and predictions, with comments for the construction and mining industries. 3-25 In Beck B F (ed) Applied karst geology. Proceedings of the fourth multidisciplinary conference on sinkholes and the engineering and environmental impacts of karst, Panama City/Florida/ 25-27 January 1993. A.A. Balkema, Rotterdam.

Reuter F, Tolmacev VV (1990) Bauen und Bergbau in Senkungs und Erdfallgebieten, Eine Ingenieurgeologie des Karstes. Schriftenreihe für Geologische Wissenschaften, Vol 28. Academie-Verlag, Berlin.

Remondo J, González-Díez A, Díaz de Terán JR, Cendrero A (2003a) Landslide susceptibility models utilising spatial data analysis techniques. A case study from the Lower Deba Valley, Guipuzcoa (Spain). Natural Hazards 30: 267-279

Remondo J, González A, Díaz de Terán JR, Cendrero A, Fabbri A, Chung Ch-JF (2003b) Validation of landslide susceptibility maps; examples and applications from a case study in Northern Spain. Natural Hazards 30: 437-449

Richardson JJ (2003) Local land use regulation of karst in the United States. In: Beck BF (ed). Sinkholes and the engineering and environmental impacts of karst. ASCE special publication 112, pp 492-501

Sowers GF (1996) Building on sinkholes. American Society of Civil Engineers Press. New York, 202 pp 
Yarou L, Cooper AH (1997) Gypsum karst geohazards in China. In: Beck BF, Stephenson, J.B. (eds) The Engineering Geology and Hydrogeology of Karst Terranes. Proceedings of the Sixth Multidisciplinary Conference on Sinkholes and the Engineering and Environmental Impacts of Karst Springfield/Missouri/6-9 April 1997. A.A.Balkema, Rotterdam. pp 117-125

Wadge G., Wislocki A, Pearson EJ, Whittow JB (1993) Mapping natural hazards with spatial modelling systems. In, Mather, P. (ed.) Geographical Information Handling Research and Applications, Wiley, pp 239-250

Waltham T, Bell F, Culshaw M (2005) Sinkholes and subsidence. Springer, Chichester, $382 \mathrm{pp}$

Warren J (1999) Evaporites. Their evolution and economics, Blackwell, Oxford, 438 pp

Williams P (1972) Morphometric analysis of polygonal karst in New Guinea. Geological Society of American Bulletin 83: 761-796

Williams P (2003) Dolines. In: Gunn J (ed) Encyclopedia of caves and karst science, Fitzroy Dearborn, New York, pp 304-310 


\section{Figures}

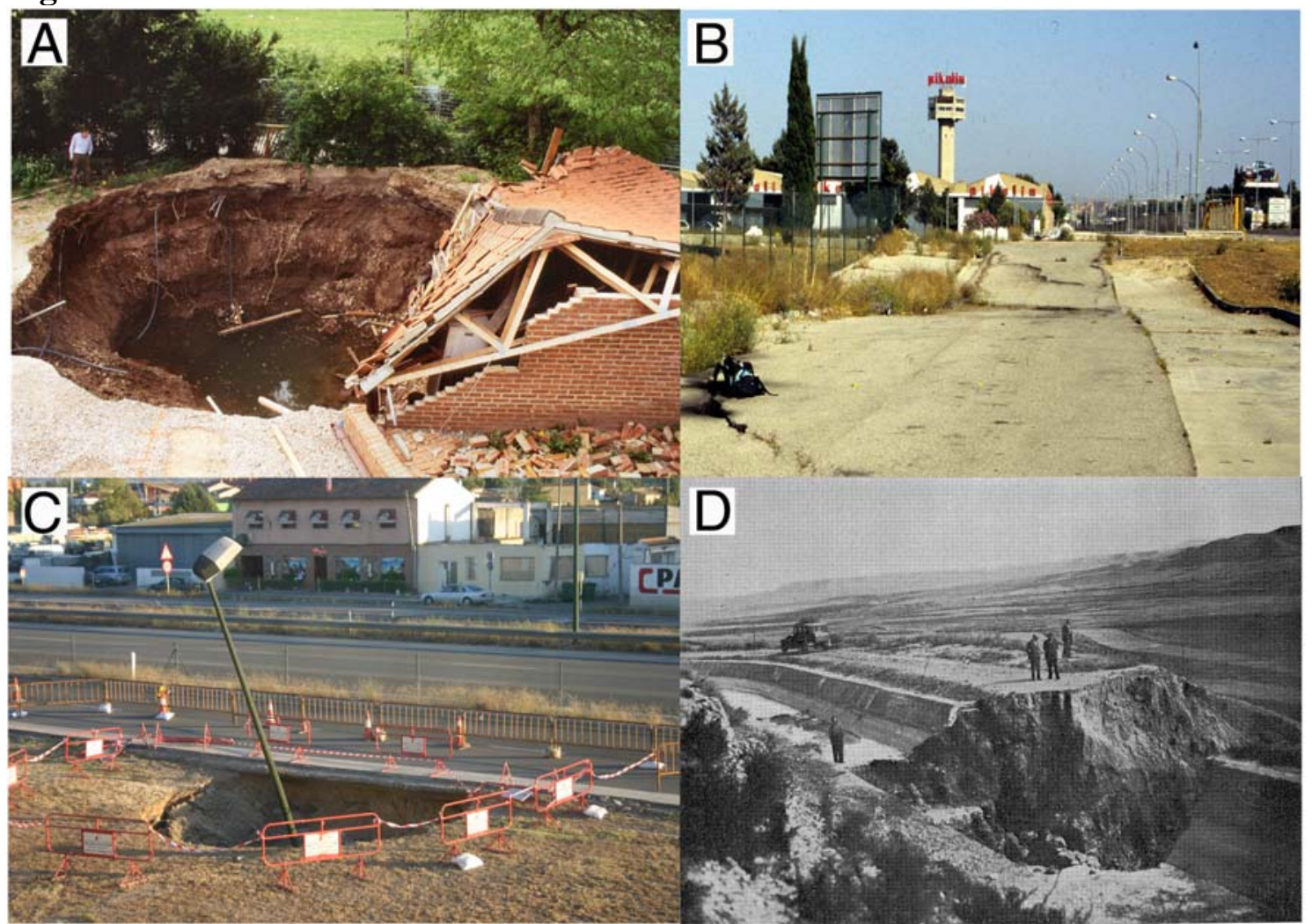

Figure 1. A: Building severely damaged by a collapse sinkhole occurred on April 23, 1997 over Permian gypsum in Ripon (NE England) photo copyright BGS, NERC. B: Bending subsidence affecting a service road located between the N-232 motorway and the Pikolín factory, on the outskirts of Zaragoza city (river terrace in the Ebro Valley, NE Spain). This stretch of the road is located over the artificially-filled sinkholes shown in figure 3. Photograph taken in June, 1996. C: Collapse sinkhole formed next to the N232 motorway during the night of May 23, 2006 (Ebro River terrace close to Zaragoza city). The three stacked artificial fills exposed in the overhanging margins suggest that this sinkhole resulted from the reactivation of a previously existing karstic depression. Photograph taken 8 days after the subsidence event. D: Collapse sinkhole that occurred in 1954 in the La Violada Canal (Ebro Tertiary Basin, NE Spain). Photograph taken from Llamas (1962). 


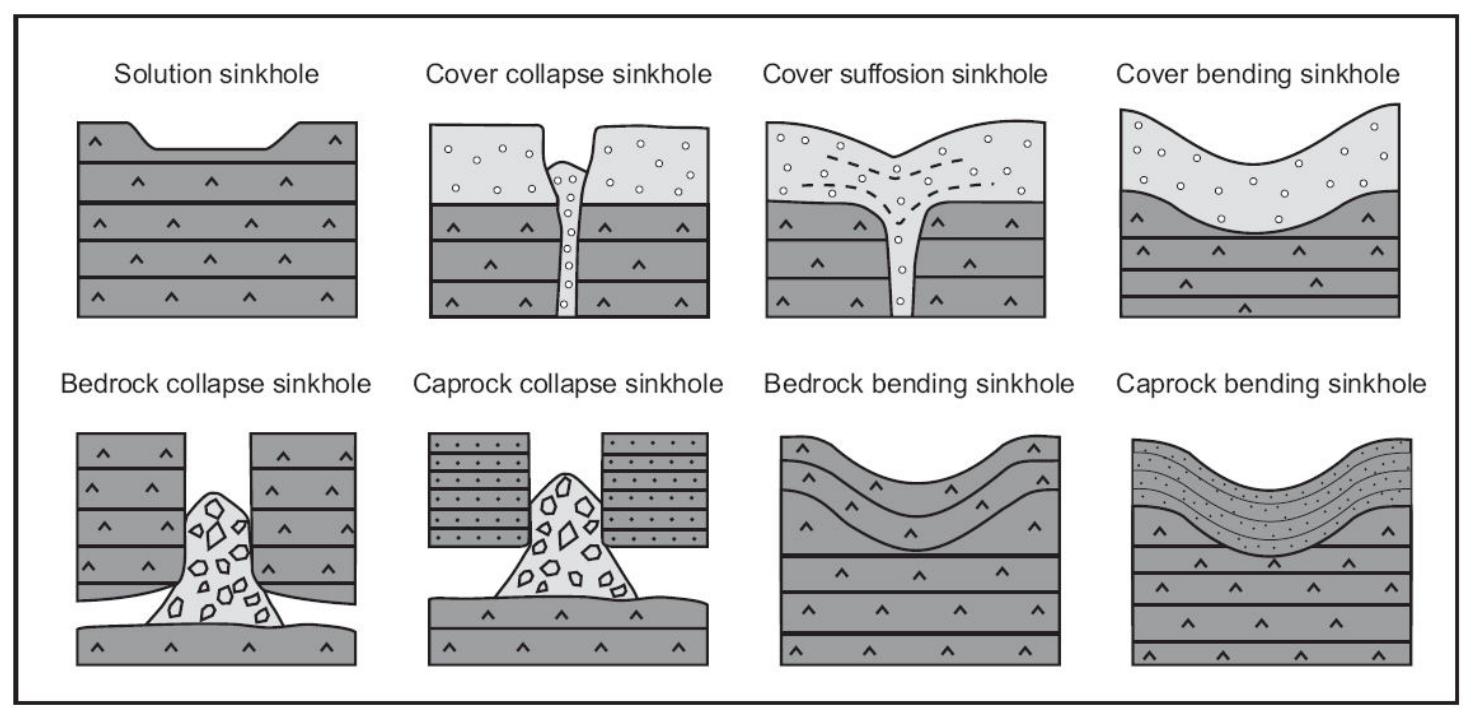

Figure 2. Genetic classification of sinkholes developed in evaporite karst areas (Gutierrez et al., 2008b). 


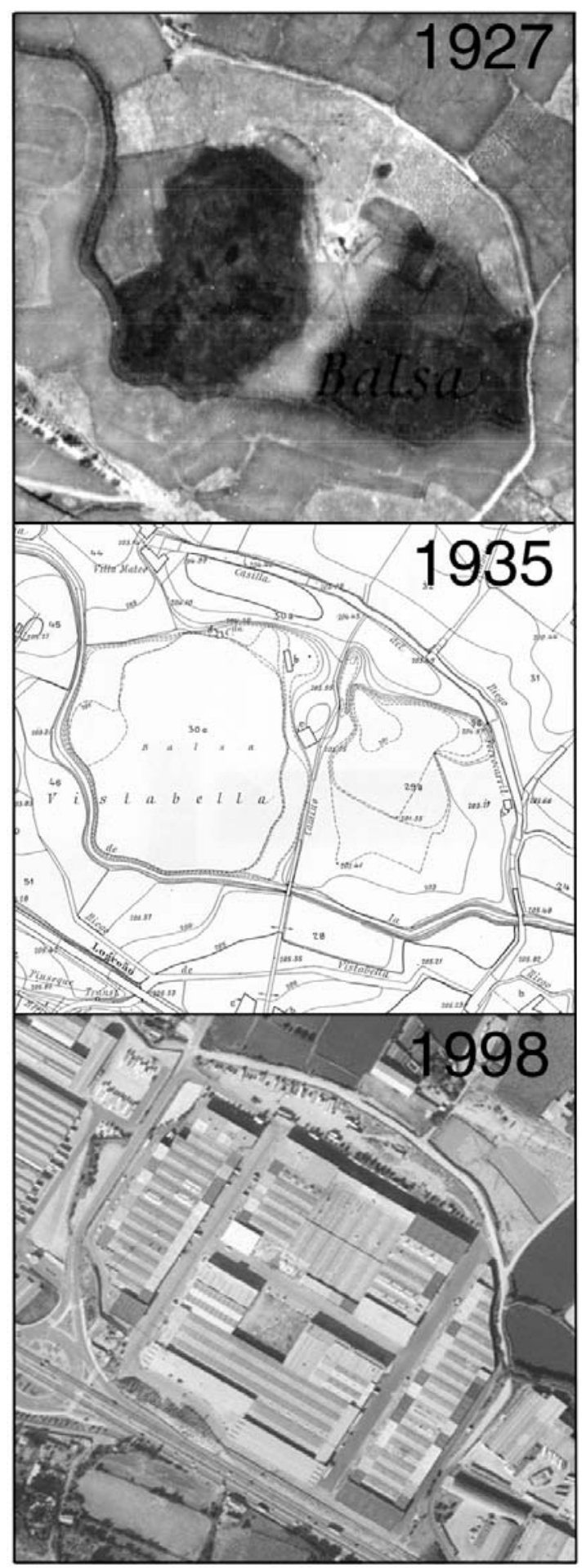

Figure 3. Identification of a buried sinkhole in a developed area using old aerial photographs and detailed topographic maps. The example corresponds to the sinkholes currently covered by the Pikolín factory (fig. 1B) next to the N-232 motorway in the outskirts of Zaragoza. The dark areas in the 1927 image show swamped areas developed in 2 sinkholes. The dashed contour lines in the 1935 topographic map, 1:2,000 in scale, represent the extent and geometry of the dolines. The 1998 image shows the buildings constructed on the sinkholes. These buildings and the adjacent roads (fig. 3) are affected by gradual subsidence and a catastrophic collapse formed inside one of them a few years ago. 


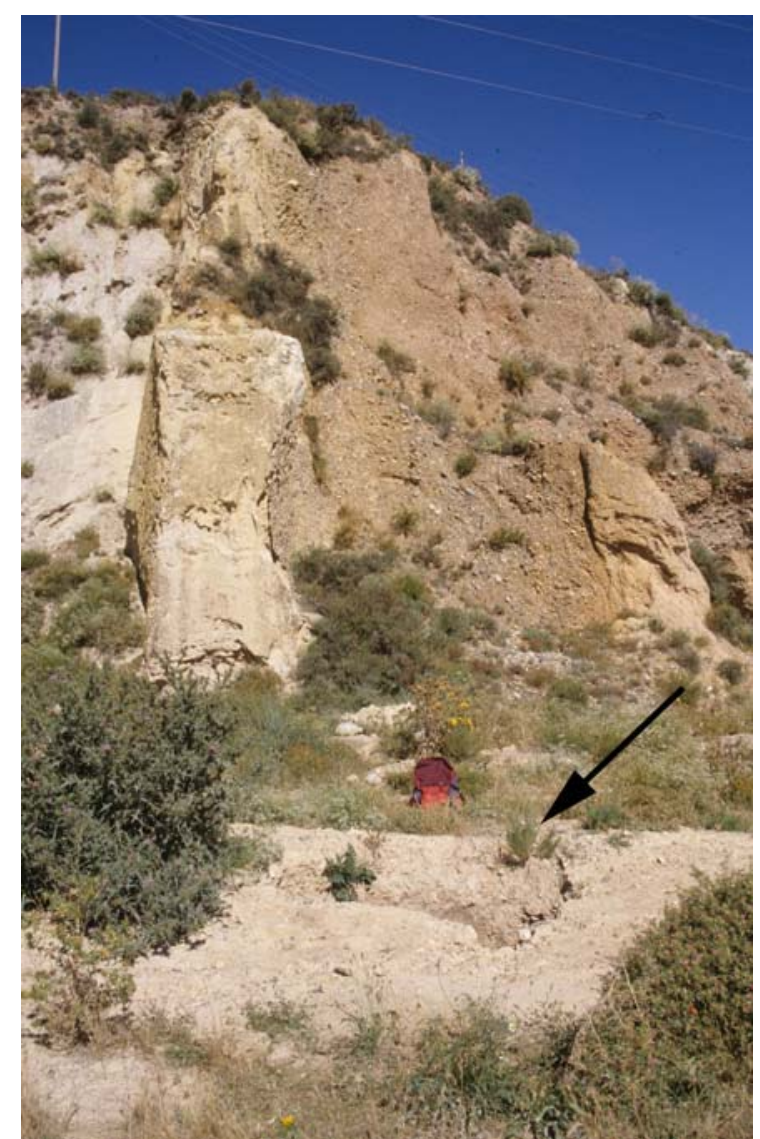

Figure 4. Collapse sinkhole developed next to a paleocollapse structure affecting Quaternary terrace deposits of the Alfambra River (Teruel Neogene Graben, NE Spain). This active sinkhole, affecting a recent artificial fill, most likely results from the reactivation of old cavities recorded by the adjacent paleosubsidence structures. Photograph taken on July 27, 1997.

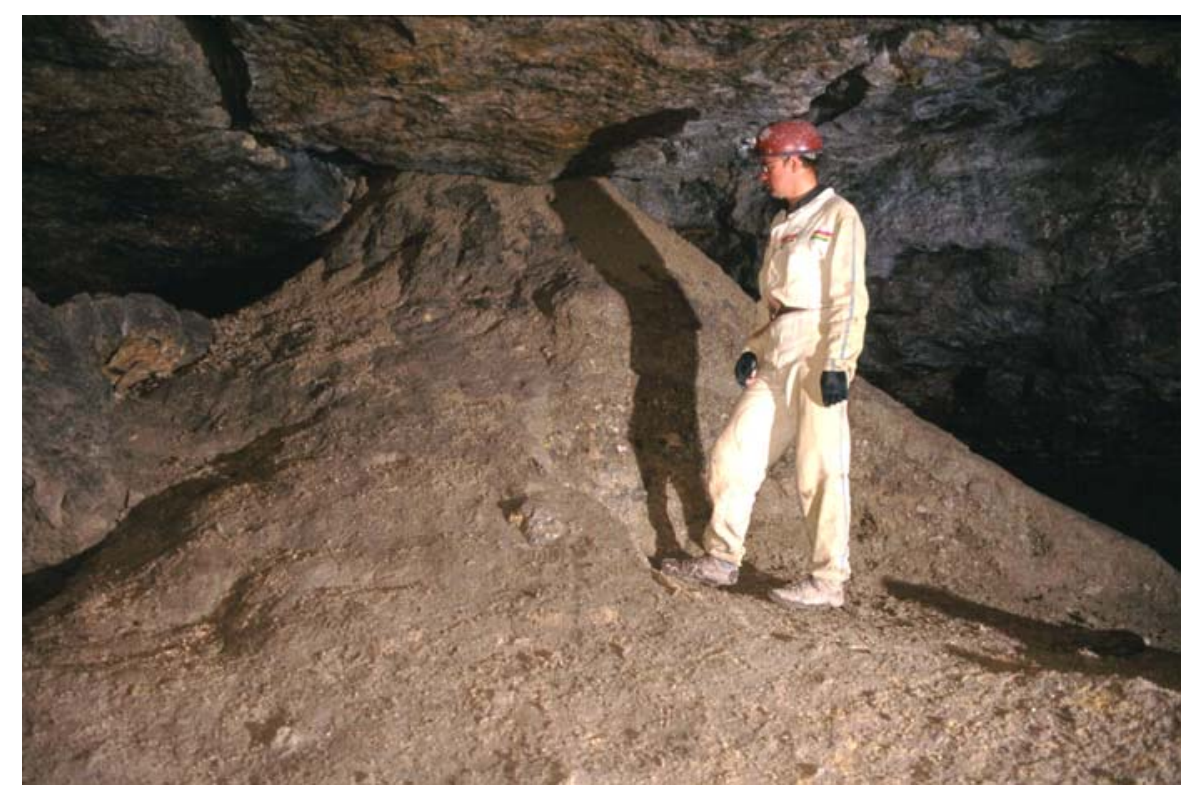

Figure 5. Fresh debris cone in the Mylinki Cave (gypsum karst of western Ukraine) generated by the active upward propagation of a joint-controlled cavity. This accumulation allows identifying the probable location of a future sinkhole. Photograph taken in May 1999, copyright BGS, NERC. 


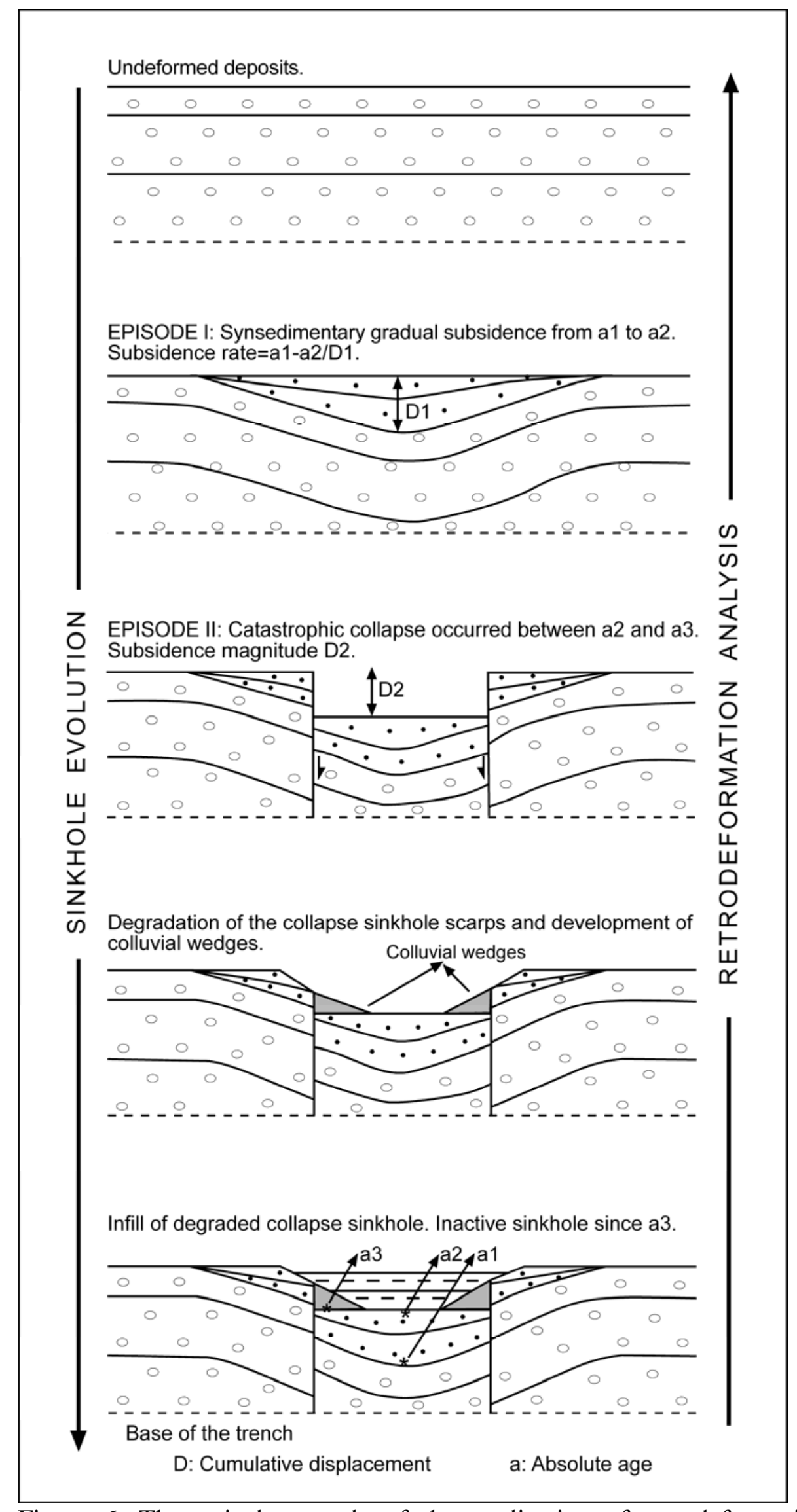

Figure 6. Theoretical example of the application of retrodeformation analysis and absolute dating techniques to the investigation of sinkholes in a mantled karst setting. 
Sinkholes before year $\mathrm{X}$, in a $3 \mathrm{~km}^{2}$ area

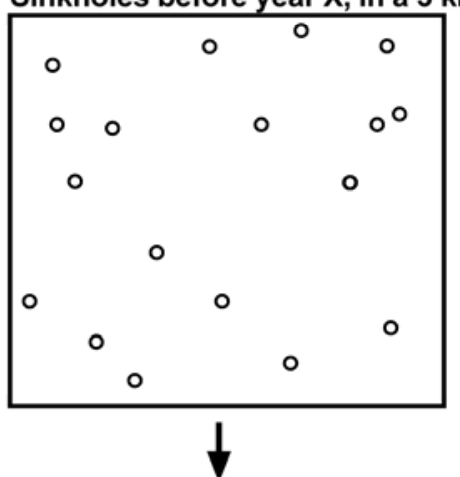

Susceptibility zonation

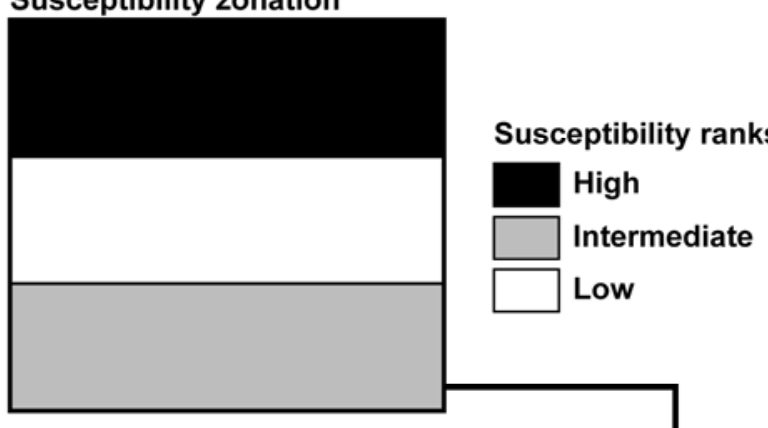

Sinkholes formed 10 years after $X$ (validation)

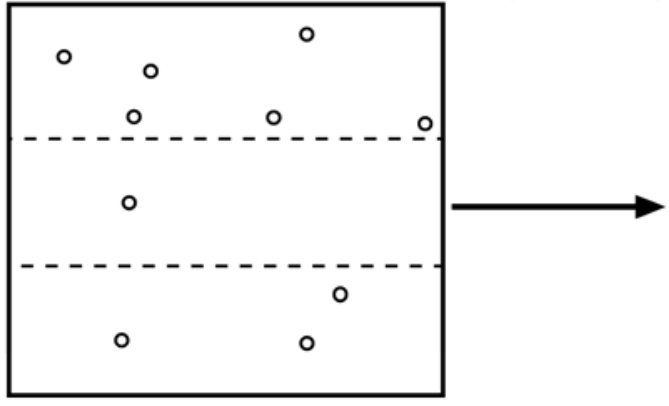

Validation and transformation into a

probability

map

\section{Probability map}

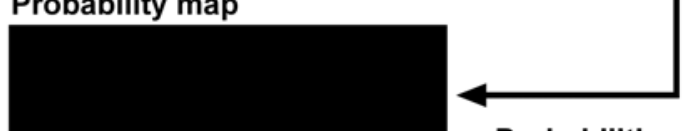

Probabilities

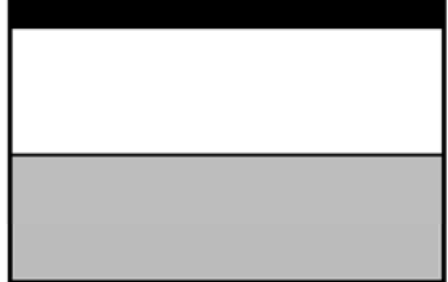

6 Sinkholes $/ \mathrm{km}^{2}$ year

3 Sinkholes $/ \mathrm{km}^{2}$ year

1 Sinkholes $/ \mathrm{km}^{2}$ year

Figure 7. Theoretical example showing the temporal validation of a sinkhole susceptibility zonation and its transformation into a probability map. 
Table 1 Main changes in the karst environment that may trigger or accelerate the development of sinkholes. Their main effects and the type of natural processes and human activities that may cause them are indicated.

\begin{tabular}{|c|c|c|}
\hline Type of change & Effects & $\begin{array}{l}\text { (1) Natural Processes (2) Human } \\
\text { activities }\end{array}$ \\
\hline $\begin{array}{l}\text { Increased water input to the } \\
\text { ground (cover and bedrock) } \\
\text { (Gutiérrez et al 2007a, } \\
\text { submitted data) }\end{array}$ & $\begin{array}{l}\text { Favors dissolution } \\
\text { Increases percolation accelerating } \\
\text { suffosion } \\
\text { Increases the weight of the sediments } \\
\text { May reduce the mechanical strength of } \\
\text { the sediments }\end{array}$ & $\begin{array}{l}\text { (1) Rainfall events, floods, snow } \\
\text { melting, permafrost thawing } \\
\text { (2) Irrigation, leakages from } \\
\text { utilities (pipes, canals, ditches), } \\
\text { impoundment of water, runoff } \\
\text { concentration (urbanization, } \\
\text { soakaways) or diversion, } \\
\text { vegetation removal, drilling } \\
\text { operations (Johnson, 1989), } \\
\text { unsealed wells, injection of fluids }\end{array}$ \\
\hline $\begin{array}{l}\text { Water table decline } \\
\text { (LaMoreaux and Newton } \\
\text { 1986) }\end{array}$ & $\begin{array}{l}\text { Increases the effective weight of the } \\
\text { sediments (loss of buoyant support) } \\
\text { Slow phreatic flow replaced by more } \\
\text { rapid downward percolation favoring } \\
\text { suffosion, especially when the water } \\
\text { table is lowered below the rockhead } \\
\text { May reduce the mechanical strength by } \\
\text { desiccation } \\
\text { Suction effect }\end{array}$ & $\begin{array}{l}\text { (1) Climate change, sea level } \\
\text { decline, entrenchment of drainage } \\
\text { network } \\
\text { (2) Water abstraction or de- } \\
\text { watering for mining operations, } \\
\text { decline of the water level in lakes } \\
\text { (Dead Sea) (Frumkin and Raz } \\
\text { 2001) }\end{array}$ \\
\hline $\begin{array}{l}\text { Impoundment of water } \\
\text { (Johnson 2008b) }\end{array}$ & $\begin{array}{l}\text { May create very high hydraulic } \\
\text { gradients favoring dissolution and } \\
\text { internal erosion processes } \\
\text { Imposes a load }\end{array}$ & $\begin{array}{l}\text { (1) Natural lakes } \\
\text { (2) Reservoirs, lagoons }\end{array}$ \\
\hline $\begin{array}{l}\text { Permafrost thawing } \\
\text { (Eraso et al. 1995) }\end{array}$ & $\begin{array}{l}\text { Favors dissolution } \\
\text { Significant reduction in the strength of } \\
\text { the sediments }\end{array}$ & $\begin{array}{l}\text { (1) Climate change } \\
\text { (2) Development, deforestation }\end{array}$ \\
\hline $\begin{array}{l}\text { Static loads } \\
\text { (Waltham et al. 2005) }\end{array}$ & $\begin{array}{l}\text { Favors the failure of cavity roofs and } \\
\text { compaction processes }\end{array}$ & $\begin{array}{l}\text { (1) Aggradation processes } \\
\text { (2) Engineered structures, } \\
\text { dumping, heavy vehicles } \\
\end{array}$ \\
\hline Dynamic loads & $\begin{array}{l}\text { Favors the failure of cavity roofs and } \\
\text { may cause liquefaction-fluidization } \\
\text { processes involving a sharp reduction } \\
\text { in the strength of soils }\end{array}$ & $\begin{array}{l}\text { (1) Earthquakes (Michetti et al. } \\
\text { 2005), explosive volcanic } \\
\text { eruptions } \\
\text { (2) Artificial vibrations (blasting, } \\
\text { explosions) }\end{array}$ \\
\hline $\begin{array}{l}\text { Thinning of the sediments } \\
\text { over voids } \\
\text { (Guerrero et al. 2004) }\end{array}$ & $\begin{array}{l}\text { Reduces the mechanical strength of } \\
\text { cavity roofs } \\
\text { May concentrate runoff and create a } \\
\text { local base level for groundwater flows }\end{array}$ & $\begin{array}{l}\text { (1) Erosion processes } \\
\text { (2) Excavations }\end{array}$ \\
\hline $\begin{array}{l}\text { Underground excavations } \\
\text { (Lucha et al. 2008) }\end{array}$ & $\begin{array}{l}\text { Disturb groundwater flows } \\
\text { May weaken sediments over voids }\end{array}$ & $\begin{array}{l}\text { (1) Biogenic pipes } \\
\text { (2) Mining, tunneling }\end{array}$ \\
\hline
\end{tabular}


Table 2. Main advantages and disadvantages of the most commonly used geophysical methods for the detection of cavities, subsidence structures and buried sinkholes (Based on Hoover 2003 and Waltham et al. 2005).

\begin{tabular}{|c|c|c|}
\hline Geophysical method (output)) & Advantages & Disadvantages \\
\hline $\begin{array}{l}\text { Electrical resistivity } \\
\text { (Profiles showing the resistance of } \\
\text { the ground to the passage of an } \\
\text { electric current; the technique can } \\
\text { also be used to construct maps and } \\
\text { 3D tomographic surveys) }\end{array}$ & $\begin{array}{l}\text { Not affected by vibrations } \\
\text { and irregular topography } \\
\text { Can provide full 3D } \\
\text { tomographic surveys, but } \\
\text { depth of resolution } \\
\text { decreases around the } \\
\text { margins; depth of } \\
\text { penetration up to about } \\
\text { 40m. Fast acquisition if } \\
\text { done with automated } \\
\text { computerized equipment. }\end{array}$ & $\begin{array}{l}\text { Interferences from utilities like } \\
\text { buried electric lines and wire } \\
\text { fences. } \\
\text { Does not work on man-made } \\
\text { surfaces like tarmac and concrete } \\
\text { The soil moisture reduces the } \\
\text { quality of the results } \\
\text { Slow acquisition of data if done } \\
\text { manually. } \\
\text { Anomalies must be checked with } \\
\text { intrusive methods }\end{array}$ \\
\hline $\begin{array}{l}\text { Electromagnetic conductivity -EM } \\
\text { (Maps showing the conductivity of } \\
\text { the ground in plan view) }\end{array}$ & $\begin{array}{l}\text { Rapid acquisition of data } \\
\text { Not affected by vibrations } \\
\text { and irregular topography } \\
\text { Does not require sensors to } \\
\text { be placed on the ground }\end{array}$ & $\begin{array}{l}\text { Interferences from utilities, } \\
\text { buildings, and metallic structures } \\
\text { Limited depth of penetration } \\
\text { Anomalies must be checked with } \\
\text { intrusive methods }\end{array}$ \\
\hline $\begin{array}{l}\text { Ground penetrating radar- GPR } \\
\text { (Profiles showing reflectors that } \\
\text { represent variations in the ground's } \\
\text { electrical impedance) }\end{array}$ & $\begin{array}{l}\text { Rapid acquisition of data } \\
\text { Allows one to identify the } \\
\text { geometry of dissolution } \\
\text { and subsidence features }\end{array}$ & $\begin{array}{l}\text { Limited depth of penetration } \\
\text { Penetration reduced by conductive } \\
\text { materials (clay and water) } \\
\text { Interferences from external } \\
\text { electromagnetic fields }\end{array}$ \\
\hline $\begin{array}{l}\text { Microgravimetry } \\
\text { (Profiles or maps showing minute } \\
\text { changes in the Earth's gravitational } \\
\text { field) }\end{array}$ & $\begin{array}{l}\text { May be used satisfactorily } \\
\text { on man-made surfaces, } \\
\text { near or within buildings } \\
\text { and next to electrical } \\
\text { sources }\end{array}$ & $\begin{array}{l}\text { Slow and requires accurate surface } \\
\text { leveling plus complex correction } \\
\text { calculations } \\
\text { Difficult in areas with significant } \\
\text { topographic relief } \\
\text { Anomalies must be checked with } \\
\text { intrusive methods } \\
\text { Small dissolution and subsidence } \\
\text { features need to be at shallow depth }\end{array}$ \\
\hline $\begin{array}{l}\text { Cross-hole tomography } \\
\text { (Profiles or 3-D images showing } \\
\text { changes in the ground's seismic } \\
\text { transparency or electrical resistivity) }\end{array}$ & $\begin{array}{l}\text { May be used satisfactorily } \\
\text { in developed areas } \\
\text { May provide 3-D images }\end{array}$ & $\begin{array}{l}\text { Requires pairs of boreholes } \\
\text { Expensive when boreholes need to } \\
\text { be drilled }\end{array}$ \\
\hline
\end{tabular}

